J. Clin. Chem. Clin. Biochem.

Vol. 19, 1981, pp. 67-70

\title{
Rapid and Sensitive Immunochemical Determination of Immunoglobulins by Centrifugal Analysis
}

\author{
By G. J. Marell and P. J. Brombacher
}

Department of Clinical Chemistry, De Wever-Ziekenhuis, Heerlen, The Netherlands

(Received March 20/August 28, 1980)

Summary: The measurement of immunoglobulin concentrations in serum by a turbidimetric method using a centrifugal analyser (Cobas Bio) is described. In the procedure described it is possible to measure the absorbance of each sample in the buffer reagent in a preliminary run without antiserum (sample blank for correction of colour, turbidity, etc.) In the main run (after adding antiserum) a final measurement is made after 600 seconds reaction time and the difference between the final absorbance and the sample blank is corrected for the absorbance of the antiserum determined in the antiserum blank cuvet. The initial phase of the reaction can thus be taken into account so that high titre antisera can be used. Therefore the method covers a wide range of values with good precision.

\section{Schnelle und empfindliche immunchemische Bestimmung von Immunglobulinen mit Zentrifugal-Analyse}

Zusammenfassung: Beschrieben wird die turbidimetrische Bestimmung von Immunglobulinkonzentrationen im Serum unter Verwendung eines Zentrifugalanalysators (Cobas Bio). In diesem Verfahren ist es möglich, Leerwertabsorptionen im Reagenz ohne Antiserum für jede Probe in einem vorhergehenden Meßvorgang zu bestimmen. Auf diese Weise wird für die endogene Farbe und Trübung der Proben korrigiert. Im Analysenmeßgang wird dann nach Zugabe des Antiserums die Absorption nach 600 Sekunden Reaktionszeit unter Berücksichtigung des Antiserumleerwertes bestimmt. Auf diese Weise kann die Initialphase der Reaktion miterfaßt werden, wodurch die Anwendung hochtitriger Antiseren ermöglicht wird. Die Methode ergibt eine gute Genauigkeit in einem weiten Konzentrationsbereich.

\section{Introduction}

A number of methods for the rapid determination of immunoglobulins have become available in recent years and both nephelometric techniques have been described. Several of these procedures, however, have disadvantages such as the necessity of pretreatment of samples (1), long reaction time in end-point analysis (2), difficulties in obtaining acceptable blank values (3) or the use of rather large samples, often combined with the need for special apparatus. Another disadvantage in some existing procedures has been the unclear starting point in kinetic analysis due to nonspecific variable turbidity of the cuvet contents. We present an improved method for the immunochemical determination of proteins in biological fluids including immunoglobulins in serum, using fixed time centrifugal analysis. A centrifugal analyser (Cobas Bio Analyser, Hoffmann-LaRoche) was chosen on account of its wide applicability in clinical chemistry, thus avoiding the purchase of expensive special apparatus. The result of this choice of apparatus was that a turbidimetric measuring method had to be developed because nephelometry was not possible with this analyser. A subsequent decision whether to perform measurement of reaction kinetics or end-point analysis had also to be made. For efficiency reasons we adopted fixed time analysis and were thus able to use high titre antisera. The use of these is often cumbersome in continuous kinetic analysis. In fixed time analyses, reaction conditions can be adapted so that the risk of reading on the descending slope of the so-called Heidelberger curve is excluded. Moreover, the reaction time can be limited. Finally the sensitivity of the method is considerably enhanced by the determination of sample blanks in a preliminary run.

\section{Materials and Methods}

\section{Reagents}

1. Buffer solution. Phosphate buffer $0.07 \mathrm{~mol} / 1 \mathrm{pH} 7.5$, containing $25 \mathrm{~g} / 1$ polyethylene glycol -6000 .

2. Freeze-dried ovine antisera. 
3. Aqueous solution of polyethylene glycol $-6000,150 \mathrm{~g} / \mathrm{l}$.

4. Immunoglobulin standards.

5. Aqueous solution of $\mathrm{NaCl}, 9 \mathrm{~g} / \mathrm{l}$.

6. Reagents for immunodiffusion determination of immunoglobulins.

Regants 1-4 (Tinaquant ${ }^{\circledR}$ ) were obtained from Boehringer Mannheim GmbH; reagent 6 (Tripartigen ${ }^{\circledR}$ ) was obtained from Behringwerke AG, Marburg.

\section{Procedure}

Buffer reagent is prepared immediately before use by mixing $100 \mathrm{ml}$ of buffer solution with $10 \mathrm{ml}$ of reagent 3 .

The starting reagent is prepared by dissolving the lyophilized antiserum in $4 \mathrm{ml}$ of the buffer reagent.

Serum samples and immunoglobulin standards are diluted $1: 50$ with reagent 5 . Standard concentrations from 6 to $26 \mathrm{~g} / 1$ for IgG, from 1 to $6 \mathrm{~g} / 1$ for $\operatorname{lgA}$ and from 0.7 to $3.0 \mathrm{~g} / 1$ for IgM are used.

The reaction is performed in the centrifugal analyser: specifications are given in table 1.

Tab. 1. Scheme for the determination of immunoglobulins in serum by centrifugal analysis (Cobas Bio). Specifications:

$3,4,5$ - concentrations of standards as used by us

8 - machine code indicating method using blank measurement from preliminary run

13 - concerns preliminary run

15 - machine code indicating the beginning of the $600 \mathrm{~s}$ interval; this reading is not used

- indicates antiserum reagent blank

- prints difference in absorbances between preliminary run and main run

\begin{tabular}{|c|c|c|c|c|}
\hline & & IgG & IgA & IgM \\
\hline 1. & Units & $\mathrm{g} / 1$ & $g / 1$ & $g / 1$ \\
\hline 2. & Calculation factor & 0 & 0 & 0 \\
\hline 3. & Standard I concentration & 6.66 & 1.34 & 0.75 \\
\hline 4. & Standard II concentration & 13.08 & 2.80 & 1.55 \\
\hline 5. & $\begin{array}{l}\text { Standard III concentra- } \\
\text { tion }\end{array}$ & 25.53 & 5.43 & 2.81 \\
\hline 6. & Limit & 30.0 & 6.0 & 4.0 \\
\hline 7. & Temperature & 25.0 & 25.0 & 25.0 \\
\hline 8. & Type of analysis & 7 & 7 & 7 \\
\hline 9. & Wavelength (nm) & 340 & 340 & 340 \\
\hline 10. & $\underset{(\mu 1)}{\text { Sample (diluted) volume }}$ & 10 & 25 & 50 \\
\hline 11. & $\begin{array}{l}\text { Diluent (water) volume } \\
(\mu l)\end{array}$ & 70 & 55 & 30 \\
\hline 12. & Reagent volume $(\mu \mathrm{l})$ & 200 & 200 & 200 \\
\hline 13. & Incubation time (s) & 30 & 30 & 30 \\
\hline 14. & Start reagent volume $(\mu \mathrm{l})$ & 50 & 50 & 50 \\
\hline 15. & Time of first reading (s) & 1.0 & 1.0 & 1.0 \\
\hline 16. & Time interval (s) & 600 & 600 & 600 \\
\hline 17. & Number of readings & 2 & 2 & 2 \\
\hline 18. & Blanking mode & 1 & $i$ & 1 \\
\hline 19. & Print out mode & 5 & 5 & 5 \\
\hline
\end{tabular}

\section{Results and Discussion}

\section{Kinetics of the immuno complex formation}

A problem in following the kinetics of an immunochemical reaction by measuring increasing turbidity is the fact that initially there often is no linear relation between the absorbances measured and the reaction rate. During the first minute of the reaction most peculiar absorbances can be observed, partly due to the non-ho- mogeneity of the reaction mixture in the starting phase. In this period the regularity of kinetics which appears after one minute has not yet been reached. Therefore a so-called fixed time measurement procedure is often. used. An evident drawback is that, expecially in the measurement of elevated protein concentrations and correspondingly increased reaction rates, a considerable part of the reaction proceeds in the first minute and is thus not observed. The rate of increase of absorbance gradually slows down as the reaction proceeds. Therefore, only taking the differences in absorbances at 1 minute and after 5 minutes more into account, unfavourably influences the precision of the determination (fig. 1). The use of high titre antiserum solutions is virtually impossible in this procedure, because the greatest part of the reaction proceeds during the first, unobserved minute (fig. 1).

Using low titre antisera, however, inevitably restricts the range of values that can be measured.

Many samples have to be analysed a second time after appropriate dilution based on the observations in the first analysis. Needless to say, this causes a considerable extra amount of work.

Moreover, in order to further enhance the sensitivity of the reaction the use of polyethylene glycol in this type of determination is generally recommended $(4,5,6)$.

Sedimentation rates and quantity of precipitate are dependent on both the size of the immuno complexes and the molecular mass and concentration of the added polymers (7). The light scattering increases and the reaction rate of complex formation is said to be enhanced $(8,9)$. This is partly explained by the hypothesis that adding polyethylene glycol to the solution decreases the effective volume available for dissolving large molecules (gel filtration effect) (10).

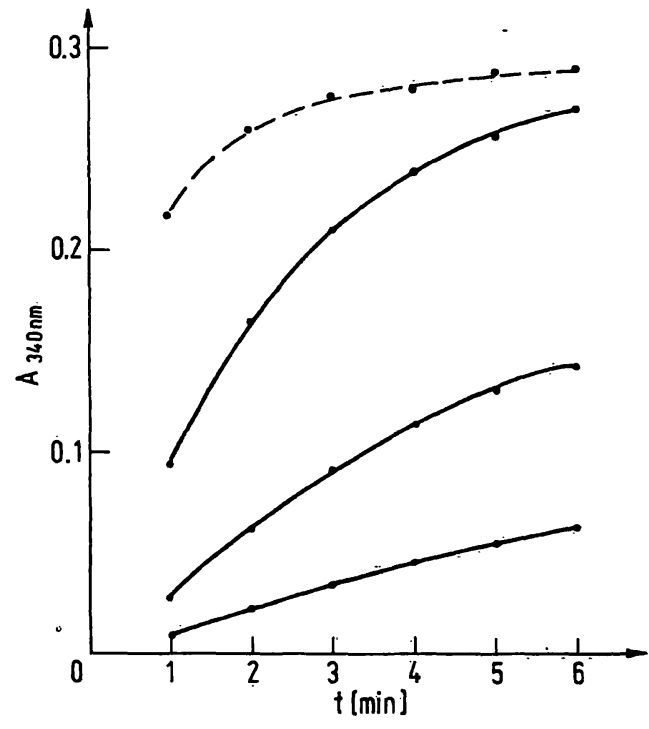

Fig. 1. Reaction of antiserum with human serum IgG; concentrations $6.6 \mathrm{~g} / 1,12.4 \mathrm{~g} / 1$ and $24.4 \mathrm{~g} / 1$ using low titre antiserum (solid lines) and $24.4 \mathrm{~g} / \mathrm{l}$ úsing high titre antiserum (broken line). 
We followed the recommendations cited above and increased the polyethylene glycol content in the buffer reagent to $36 \mathrm{~g} / \mathrm{l}$.

\section{Measurement of sample blanks in a preliminary run}

In an attempt to bypass the difficulties described we determine the absorbance of each sample in its own cuvet in the incomplete reagent mixture (without antiserum), to obtain a sample blank correcting for colour (bilirubin, haemoglobin), turbidity, etc. This measurement is made in a preliminary run. In the main run immediately afterwards the reaction is started by adding antiserum and a final reading is made after 600 seconds from the start for each cuvet. In the main run an antiserum blank is taken which is used in the calculation together with the sample blanks from the preliminary run. It appears to be possible to use the sample blanks measured in a preliminary run, thus avoiding meaningless irregular and unreproducible measurements in the initial phase of the reaction due to insufficient homogeneity of the cuvet contents. The great advantage is that the whole reaction period right from the moment of adding the antiserum can be taken into account, which as already explained, is not possible in continuous kinetic analysis. In fact, modified two point kinetics are employed. High titre antisera can now be used, so avoiding the necessity of making frequent dilutions.

\section{Performance of the procedure}

The advantages of kinetic measurement i.e. involvement of the first minute, and end-point determination are thus combined, resulting in a convenient procedure in which a repeat analysis after extra dilution is almost never necessary. Using this new procedure the top of the Heidelberger curve is reached at concentrations of $v i z .70 \mathrm{~g} / \mathrm{l}$ for IgG, $25 \mathrm{~g} / 1$ for IgA and $20 \mathrm{~g} / 1$ for IgM (fig. 2) in the samples. It is clear that measurements have to be made on the steep part of the ascending limb for reasons of accuracy.

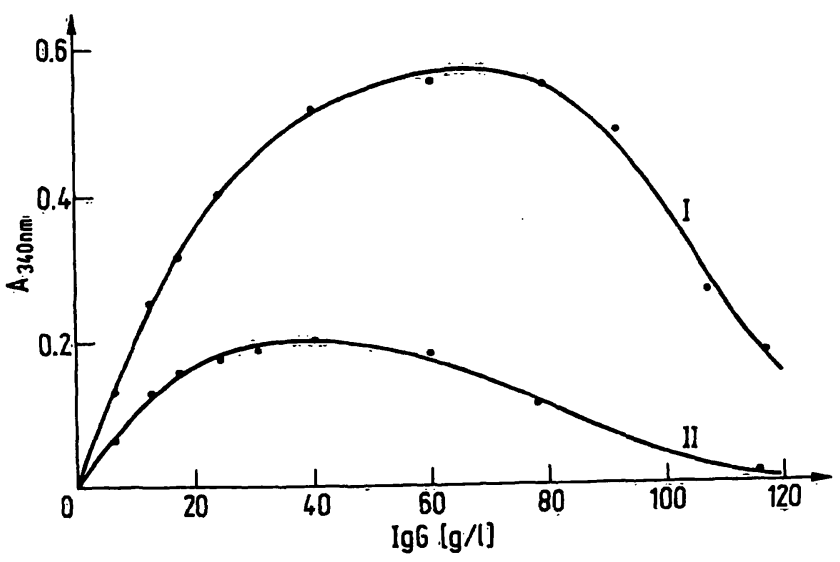

Fig. 2. Measurement of IgG concentration (see text):

I by the described procedure using high titre antiserum II by a technique subtracting $A_{1}$ min from $A_{6}$ min.
Corresponding absorbances on the descending slope of the curve must be correlated to extremely high values hardly ever seen in human serum whilst normal and considerably elevated values are always measured correctly. It follows that upper limits for viz. IgG $30 \mathrm{~g} / \mathrm{l}, \operatorname{IgA} 6.0$ $\mathrm{g} / \mathrm{l}$ and $\mathrm{IgM} 4.0 \mathrm{~g} / \mathrm{l}$ can be regarded to be on the safe side. From the curve it can be seen that a value of e.g. $30 \mathrm{~g} / \mathrm{l}$ for IgG might be confused, if at all, with a value of 93 $\mathrm{g} / \mathrm{l}$, which is an acceptable risk.

Of course, the procedure described here is only useful when the upper limit is fixed sufficiently high for nearly all samples to be correctly analysed, which is indeed the case with immunoglobulins in serum.

\section{Interference from endogenous substances}

In order to establish the possible interference from some endogenous substances, some serum samples were enriched with bilirubin, haemoglobin or triglycerides. This was done because often jaundiced sera or slightly turbid sera containing triglycerides are submitted for analysis. Moreover, samples received from the paediatric wards often are more or less haemolysed, so that the influence of haemoglobin had also to be studied. Samples were spiked by adding either a small amount of a concentrated bilirubin solution, a triglyceride emulsion or a concentrated haemolysate of washed erythrocytes. From the data presented in table 2 it can be concluded that none of the added substances changes the results of the analysis. No interference at all is seen, which means that no special attention has to be paid to yellow or turbid or haemolysed sera. This absence of interference can also be ascribed to the determination of pre-reaction sample blanks.

\section{Correlation of centrifugal analysis with radial immuno diffusion}

We determined the immunoglobulin content of a number of sera, amongst them some lipaemic and/or strongly coloured samples, both using the method described and

Tab. 2. Determination of immunoglobulins in sera enriched with bilirubin, haemoglobin and triglycerides. Final concentrations of additions in the sera are given. Immunoglobulin contents as found in $\mathrm{g} / \mathrm{l}$.

\begin{tabular}{|c|c|c|c|c|c|}
\hline & $\begin{array}{l}\text { Sample } \\
\text { No. }\end{array}$ & $\begin{array}{l}\text { No } \\
\text { additive }\end{array}$ & $\begin{array}{l}\text { Bilirubin } \\
\text { added } \\
200 \mu \mathrm{mol} / \mathrm{l}\end{array}$ & $\begin{array}{l}\text { Haemoglobin } \\
\text { added } \\
0.11 \mathrm{mmol} / 1\end{array}$ & $\begin{array}{l}\text { Triglycerides } \\
\text { added } \\
5.8 \mathrm{mmol} / \mathrm{l}\end{array}$ \\
\hline IgG & $\begin{array}{l}1 \\
2 \\
3\end{array}$ & $\begin{array}{r}9.1 \\
13.9 \\
12.5\end{array}$ & $\begin{array}{r}9.2 \\
14.1 \\
12.1\end{array}$ & $\begin{array}{r}9.3 \\
14.1 \\
12.4\end{array}$ & $\begin{array}{r}9.2 \\
13.7 \\
12.4\end{array}$ \\
\hline IgA & $\begin{array}{l}1 \\
2 \\
3\end{array}$ & $\begin{array}{l}2.20 \\
1.13 \\
3.06\end{array}$ & $\begin{array}{l}2.22 \\
1.12 \\
3.10\end{array}$ & $\begin{array}{l}2.21 \\
1.09 \\
3.02\end{array}$ & $\begin{array}{l}2.17 \\
1.09 \\
3.05\end{array}$ \\
\hline IgM & $\begin{array}{l}1 \\
2 \\
3\end{array}$ & $\begin{array}{l}0.62 \\
1.48 \\
1.50\end{array}$ & $\begin{array}{l}0.61 \\
1.52 \\
1.57\end{array}$ & $\begin{array}{l}0.66 \\
1.48 \\
1.48\end{array}$ & $\begin{array}{l}0.61 \\
1.46 \\
1.55\end{array}$ \\
\hline
\end{tabular}



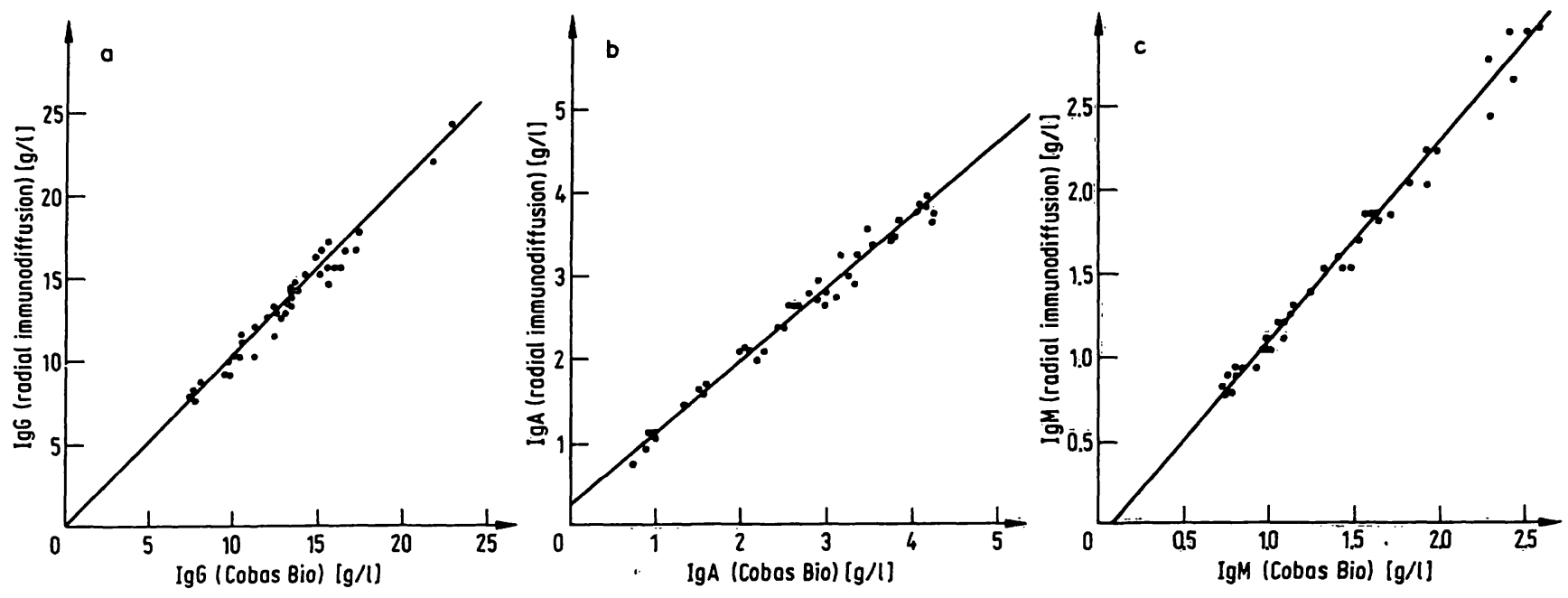

Fig. 3. Correlation of immunoglobulin determination by centrifugal analysis (Cobas Bio) vs. radial immuno diffusion.

a) IgG $y=1.02 x-0.05$; correlation coefficient $0.983 ; n=45$

b) IgA $y=0.85 x+0.29$; correlation coefficient $0.990 ; n=40$

c) $\operatorname{IgM} y=1.17 x-0.07 ;$ correlation coefficient $0.992 ; n=44$.

by radial immuno diffusion $(11,12)$. A linear correlation was found from which it can be concluded that neither the addition of polyethylene glycol in our procedure nor elevated levels of bilirubin, haemoglobin or lipids produce interference in the centrifugal analysis. In fact excellent correlation between the two methods was found for all immunoglobulins (fig. 3a , 3b, 3c).

\section{Precision and recovery}

The precision of the method described has been calculated from the determination of duplicate analyses. Variation coefficients both within series and from day to day are quite satisfactory (tab. 3).

\section{References}

1. Hellsing, K. \& Enström, H. (1977), Scand. J. Clin. Lab. Invest. $37,529-536$.

2. Killingsworth, L. M. \& Savory, J. (1973), Clin. Chem. 19, 403-407.

3. Neumann, U., Kretzler, D., Munz, E., Schrappe, K. H. \& Ziegenhorn, J. (1978), Lab. Med. 2, 62-68.

4. Hellsing, K. (1972), Automated immuno-precipitin reactions. New methods, new techniques and evaluations. Tarrytown (New York), Technicon Instruments Corp., 17-19.

5. Killingsworth, L. M., Buffone, G. J., Sonawane, M. B. \& Lunsford, G. C., (1974), Clin. Chem. 20, 1548-1552.

6. Prellwitz, W., Kapp, S. \& Müller D. (1974), Z. Klin. Chem. Klin. Biochem. 12, 427-431.
Tab. 3. Precision of immunoglobulin determination.

\begin{tabular}{lll}
\hline & $\begin{array}{l}\text { CV (\%) } \\
\text { within series } \\
(\mathrm{n}=25)\end{array}$ & $\begin{array}{l}\text { CV (\%) } \\
\text { day to day } \\
(\mathrm{n}=46)\end{array}$ \\
Range $\mathrm{g} / 1$ & 1.13 & 2.34 \\
\hline IgG $7.2-31.8$ & 0.98 & 2.50 \\
IgA $0.48-8.12$ & 1.86 & 2.97 \\
\hline IgM $0.32-2.95$ & \\
\hline
\end{tabular}

The mean recovery of immunoglobulins added to serum samples is $102 \%$ (range $97-107 \%$ ) for $\mathrm{IgG}, 96 \%$ (range 93-99\%) for IgA and 95\% (range 92-98\%) for IgM.

We conclude that the determination described is suitable for use in laboratories for clinical chemistry. The method offers advantages in speed and sensitivity over earlier procedures and is in good agreement with the almost classical single radial immuno diffusion.
7. Hellsing, K. (1969), Biochem, J. 114, 145-149.

8. Hellsing, K. (1974), Protides of the Biological Fluids. (Peeters, H. ed.) Oxford, Pergamon Press, vol. 21, 579-581.

9. Harrington, J. C., Fenton, J. W. \& Pert, J. C. (1971), Immunochemistry $8,413-421$.

10. Polson, K. (1977), Prep. Biochem. 7, 129-154.

11. Mancini, G., Carbonara, A. O. \& Heremans, J. F. (1965), Immunochemistry 2, 235-254.

12. Becker, W., Rapp, W., Schwick, H. G. \& Störiko, K. (1968), Z. Klin. Chem. Klin. Biochem. 6, 113-122.

Dr. P. J. Brombacher Department of Clinical Chemistry De Wever-Ziekenhuis Henri Dunantstraat 5 NL-6401 CX Heerlen 